\title{
Implementasi Standar Sumber Daya Manusia dan Pelayanan Minimal Kesehatan di Kota Pekalongan
}

\author{
Anik Indriono \\ Fakultas Ilmu Kesehatan Universitas Pekalongan Email: anik.indriono@gmail.com
}

\begin{tabular}{l}
\hline Info Artikel \\
\hline \\
Keywords: \\
Implementation; Human \\
Resource Standards; Minimum \\
Service Standars; Hospital. \\
P-ISSN: 1412-6605 \\
E-ISSN: 2301-6426 \\
Corresponding Author: \\
Anik Indriono, \\
E-mail: anik.indriono@gmail.com \\
Standar Pelayanan minimal; \\
\\
\end{tabular}

\begin{abstract}
Hospital is a health service facility that must provide services according to applicable service standards. One of the front guards of a hospital is an Emergency Room (IGD) which will provide emergency assistance to every patient. Emergency is a condition that threatens life and disability, so it needs fast, precise, effective and quality action. This can be achieved if the hospital has a standard of service in the Emergency Room. This study aims to determine the implementation of HR standards and minimal services in hospital emergency departments. This research is a qualitative research with a sociological juridical approach. Sociological juridical is legal research that uses secondary data as initial data, which is then followed by primary data or field data. The juridical aspect in this research is the regulation of the minister of health regarding the standards of the Hospital Emergency Room and the sociological aspect is the implementation of the rules in the ministerial decree by the hospital. Sources of legal materials for this research include primary and secondary legal materials. Data collection techniques used are through interviews and literature. The results showed that the Standard Emergency Room is regulated in Law No. 44 of 2009 concerning the Hospital. In particular, the IGD standard has been regulated in the Republic of Indonesia's Minister of Health Kepmenkes No.856 / Menkes /SK/IX / 2009 regarding the standard of Hospital Emergency Room Installation. But in reality in the field, the hospital has not fully implemented these regulations, so the quality of service in the ER is less. Thus the patient's right to get quality services is neglected. According to the Hospital Law Article 29 Paragraph 1 point (a) that "Hospitals are obliged to provide safe, quality, anti-discrimination, and effective health services by prioritizing the interests of patients in accordance with Hospital service standards". The supporting factors for implementation are high human resource motivation and the inhibiting factors, namely the opportunity and cost of further study for nurses, do not yet exist.
\end{abstract}

\begin{tabular}{l}
\hline Abstrak \\
\hline Rumah sakit merupakan fasilitas pelayanan kesehatan yang harus memberikan pelayanan \\
sesuai standar pelayanan yang berlaku. Garda depan sebuah rumah saki salah satunya \\
adalah Instalasi Gawat Darurat (IGD) yang akan memberikan pertolongan \\
kegawatdaruratan kepada setiap pasien. Kegawatdaruratan adalah kondisi yang \\
mengancam nyawa dan kecacatan, sehingga perlu tindakan yang cepat, tepat, efektif dan \\
bermutu. Hal tersebut dapat dicapai jika rumah sakit mempunyai standar pelayanan di \\
Instalasi Gawat Darurat. Penelitian ini bertujuan untuk mengetahui pelaksanaan \\
Standar SDM dan Pelayanan mimimal Instalasi Gawat Darurat Rumah Sakit. Penelitian \\
ini merupakan penelitian kualitatif dengan pendekatan Yuridis Sosiologis. Yuridis \\
Sosiologis adalah penelitian hukum yang menggunakan data sekunder sebagai data \\
awalnya, yang kemudian dilanjutkan dengan data primer atau data lapangan. Aspek \\
Yuridis dalampenelitian ini adalah peraturan menteri kesehatan tentang standar Instalasi \\
Gawat Darurat Rumah Sakit dan Aspek Sosiologis adalah pelaksanan aturan-aturan \\
dalam kepmenkes tersebut oleh rumah sakit. Sumber bahan hukum penelitian ini meliputi \\
bahan hukum primer dan bahan hukum sekunder. Teknik pengumpulan data yang \\
digunakan yaitu melalui wawancara dan kepustakaan. Hasil penelitian menunjukan \\
bahwa Standar Instalasi Gawat Darurat diatur dalam Undang - Undang No. 44 tahun \\
2009 tentang Rumah Sakit. Secara khusus Standar IGD telah diatur dalam Kepmenkes \\
RI No.856/Menkes/SK/IX/2009 tentang standar Instalasi Gawat Darurat Rumah Sakit. \\
Tetapi dalam kenyataan dilapangan, Rumah Sakit belum mengimplementasikan \\
peraturan tersebut secara penuh, sehingga mutu pelayanan di IGD menjadi kurang. \\
Dengan demikian hak pasien untuk mendapatkan pelayanan yang bermutu menjadi \\
terabaikan. Menurut Undang-Undang Rumah Sakit Pasal 29 Ayat 1 butir (a) bahwa \\
"Rumah Sakit berkewajiban memberi pelayanan kesehatan yang aman, bermutu, \\
antidiskriminasi, dan efektif dengan mengutamakan kepentingan pasien sesuai dengan \\
standar pelayanan Rumah Sakit".
\end{tabular}




\section{Pendahuluan}

Rumah sakit merupakan fasilitas pelayanan kesehatan yang harus memberikan pelayanan sesuai standar pelayanan yang berlaku. Garda depan sebuah rumah sakit salah satunya adalah Instalasi Gawat Darurat (IGD) yang akan memberikan pertolongan kegawatdaruratan kepada setiap pasien yang datang tanpa terkecuali. ${ }^{1}$ Menurut undang-undang rumah sakit No. 44 Tahun 2009 Pasal 1 ayat (1) bahwa Gawat Darurat adalah keadaan klinis pasien yang membutuhkan tindakan medis segera guna penyelamatan nyawa dan pencegahan kecacatan lebih lanjut. Sehingga untuk menjamin keselamatan nyawa pasien diperlukan Sumber Daya Manusia (SDM) yang memadai atau sesuai standar, saat ini standar SDM IGD tertuang dalam Kepmenkes RI No.856/Menkes/SK/IX/2009 tentang Standar Instalasi Gawat Darurat Rumah Sakit yang selanjutnya disebut Standar IGD Rumah Sakit.

Rumah sakit sebagai salah satu fasilitas pelayanan kesehatan perorangan merupakan bagian dari sumber daya kesehatan yang sangat diperlukan dalam mendukung penyelenggaraan upaya kesehatan. Sejalan dengan amanat Pasal 28 H ayat (1) Perubahan Undang-Undang Dasar Negara Republik Indonesia Tahun 1945 telah ditegaskan bahwa setiap orang berhak memperoleh pelayanan kesehatan, kemudian dalam Pasal 34 ayat (3) dinyatakan negara bertanggung jawab atas penyediaan fasilitas pelayanan kesehatan dan fasilitas pelayanan umum yang layak. Sesuai dengan Undang - Undang No. 44 tahun 2009 tentang Rumah Sakit yang selanjutnya disebut Undang-Undang Rumah Sakit pada Pasal 5 menyebutkan bahwa rumah sakit mempunyai fungsi penyelenggaraan pelayanan pengobatan dan pemulihan kesehatan sesuai dengan standar pelayanan rumah sakit. Jenis - jenis pelayanan rumah sakit yang minimal wajib disediakan oleh rumah sakit meliputi:
a. Pelayanan gawat darurat
b. Pelayanan rawat jalan
c. Pelayanan rawat inap
d. Pelayanan bedah
e. Pelayanan persalinan dan perinatologi
f. Pelayanan intensif
g. Pelayanan radiologi
h. Pelayanan laboratorium patologi klinik
i. Pelayanan rehabilitasi medik
j. Pelayanan farmasi
k. Pelayanan gizi
1. Pelayanan transfusi darah

${ }^{1}$ Herlambang Susatyo, 2016, Manajemen Pelayanan Kesehatan Rumah Sakit, Yogyakarta: Gosyen Publishing, hlm. 33 
m.Pelayanan keluarga miskin

n. Pelayanan rekam medis

o. Pengelolaan limbah

p. Pelayanan administrasi manajemen

q. Pelayanan ambulans/kereta jenazah

r. Pelayanan pemulasaraan jenazah

s. Pelayanan laundry

t. Pelayanan pemeliharaan sarana rumah sakit

u. Pencegah Pengendalian Infeksi²

Menurut Undang-Undang Rumah Sakit Pasal 10 disebutkan bahwa Ruang Gawat Darurat adalah salah satu ruang yang disyaratkan harus ada pada bangunan rumah sakit, yang merupakan ruang pelayanan khusus yang menyediakan pelayanan yang komprehensif dan berkesinambungan selama 24 jam. Dalam rangka mewujudkan Ruang Gawat Darurat yang memenuhi standar pelayanan dan persyaratan mutu, keamanan dan keselamatan perlu didukung oleh bangunan dan prasarana (utilitas) yang memenuhi persyaratan teknis. Pasien yang masuk ke IGD rumah sakit tentunya butuh pertolongan yang cepat dan tepat untuk itu perlu adanya standar dalam memberikan pelayanan gawat darurat, supaya kecacatan dan kematian pasien dapat dicegah. ${ }^{3}$

Seperti penelelitian yang dilakukan oleh Rudi Limantara bahwa kematian di IGD masih tinggi, beberapa faktor yang menyebabkan hal tersebut terjadi antara lain: Keilmuan dan keterampilan tenaga medis masih kurang, dan Standar Prosedur Oprasioal yang belum dijalankan dengan baik. Dengan demikian Sumber Daya Manusia di IGD yang memenuhi standar mejadi prasyarat yang utama dalam menjalankan pelayanan di instalasi gawat darurat. Menurut Undang-Undang Rumah Sakit Pasal 12 ayat (1) Persyaratan sumber daya manusia sebagaimana dimaksud dalam Pasal 7 ayat (1) yaitu Rumah Sakit harus memiliki tenaga tetap yang meliputi tenaga medis dan penunjang medis, tenaga keperawatan, tenaga kefarmasian, tenaga manajemen Rumah Sakit, dan tenaga nonkesehatan. Kemudian ditegaskan pada Pasal 13 ayat (1) bahwa semua tenaga medis yang melakukan praktik kedokteran di Rumah Sakit wajib memiliki Surat Izin Praktik sesuai dengan ketentuan peraturan perundang-undangan yang berlaku dan pada Pasal 13 ayat (3) Setiap tenaga kesehatan yang bekerja di Rumah Sakit harus bekerja sesuai dengan standar profesi, standar pelayanan

2 Ibid

${ }^{3}$ Rudy Limantara, 2015, Faktor-faktor yang Mempengaruhi Tingginya Angka Kematian di IGD Rumah Sakit, Jurnal Kedokteran Brawijaya, Program Studi Magister Manajemen, Vol. 28, Suplemen No. 2, Rumah Sakit Fakultas Kedokteran Universitas Brawijaya Malang, diakses di http.jkb.ub.ac.id.index.php jkb article view 968, pada 16 Januari 2018 
Rumah Sakit, standar prosedur operasional yang berlaku, etika profesi, menghormati hak pasien dan mengutamakan keselamatan pasien.

Sanksi bagi rumah sakit yang tidak menjalankan standar dengan baik diatur dalam Undang-undang Rumah Sakit Pasal 54 Ayat (5) yaitu Pemerintah Daerah dapat mengambil tindakan administratif berupa: a. teguran; b. teguran tertulis; dan/atau c. denda dan pencabutan izin. Menurut teori sistem hukum, implementasi peraturan dan atau undang-undang merupakan bagian dari pelaksanaan hukum. Para ahli hukum menarik kerangka yang mengadung pengertian hukum yaitu: 1. Peraturan mengenai tingkah laku manusia dalam pergaulan masyarakat. 2. Peraturan itu di adakan oleh badan-badan resmi yang berwajib. 3. Peraturan itu bersifat memaksa. 4. Sanksi terhadap pelanggaran tersebut adalah tegas. Dari pengertian hukum tersebut maka dapat diambil kaedah sebagai ciri-ciri hukum yaitu: 1. Adanya perintah dan larangan. 2. Harus ditaati oleh setiap orang. 3. Jika peraturan tidak dipatuhi maka akan terkena sangsi yang tegas. ${ }^{4}$

RSUD Bendan Kota Pekalongan merupakan Lembaga Teknis Daerah yang didirikan berdasarkan Perda Kota Pekalongan No. 5 Tahun 2008, tentang Susunan Organisasi dan Tata Kerja Rumah Sakit Umum Daerah (RSUD) Bendan Kota Pekalongan. Dalam upaya untuk meningkatkan pelayanan kepada masyarakat mulai tahun 2009 RSUD Bendan Kota Pekalongan menerapkan Pola Pengelolaan Keuangan Badan Layanan Umum Daerah (BLUD). Cakupan wilayah rumah sakit ini adalah penduduk Kota Pekalongan dan sebagai rumah sakit rujukan 14 Puskesmas di Kota Pekalongan. RSUD Bendan Kota Pekalongan sejak Tahun 2009 sudah bersetatus sebagai rumah sakit kelas C. Pada tahun 2017 rumah sakit ini sudah terakreditasi paripurna oleh lembaga akreditasi KARS versi 2012. Akan tetapi angka kematian di IGD masih dibilang tinggi yaitu enam per seribu dari standar IGD yaitu kurang dari dua per seribu dalam indikator kematian pasien kurang dari 24 jam. ${ }^{5}$

Rumah Sakit Kelas C termasuk dalam standar IGD level II. Menurut Standar IGD Rumah Sakit level II, IGD rumah sakit harus dapat memberikan pelayanan antara lain: 1. Diagnosis \& penanganan: Permasalahan pada Airway, Breathing, Circulation degan alat-alat yang lebih lengkap termasuk ventilator. 2. Penilaian disability, Penggunaan obat, EKG, defibrilasi. 3. Observasi HCU/Ruang Resusitasi. 4. Bedah cito.

Kemudian telah memiliki Sumber Daya Manusia antara lain: 1. dokter spesialis Bedah, Obsgyn, Anak, Penyakit Dalam on call. 2. Dokter Umum (+Pelatihan Kegawat Daruratan) GELTS, ATLS, ACLS, dll bersedia jaga 24 jam. 3. Perawat Kepala S1 atau DIII (+Pelatihan Kegawat Daruratan) Emergency

\footnotetext{
${ }^{4}$ Agus Purwanto Erwan, 2015. Implementasi Kebijakan Publik: Konsep dan Aplikasinya di Indonesia. Yogyakarta: Gava Media, hlm. 20-21

${ }^{5}$ Data RS Online,http://sirs.yankes.kemkes.go.id/rsonline/report/home, Diunduh pada 29 Desember 2017
} 
Nursing, BTLS, BCLS dll siap jaga 24 jam. 4. Perawat (+Pelatihan Emergency Nursing) jaga 24 jam. 5. Non Medis Bagian Keuangan, Pekarya dan Kamtib (24 jam). Rumah sakit Kelas $C$ harus mempunyai minimal empat spesialistik dasar yaitu: Bedah, Penyakit Dalam, Kebidanan dan Anak. Berdasarkan latar belakang tersebut maka peneliti sangat tertarik untuk meneliti Tentang Implementasi Standar Sumber Daya Manusia (SDM) Dalam Pelayanan Gawat Darurat Menurut Kepmenkes RI No. 856/Menkes/SK/IX/2009 tentang Standar IGD Rumah Sakit di RSUD Bendan Kota Pekalongan dan Faktor Pendukung Dan Penghambat Implementasi SDM Menurut Kepmenkes Ri No.856/Menkes/SK/IX/2009.

\section{Hasil dan Pembahasan}

1. Implementasi Standar Sumber Daya Manusia dan Pelayanan Minimal Menurut Kepmenkes RI No. 856/Menkes/SK/IX/2009 di RSUD Bendan

Didalam standar IGD rumah sakit tersebut telah mengklasifikasikan pelayanan minimal rumah sakit berdasarkan lavel/tingkatan sebagai berikut:

a. Pelayanan Instalasi Gawat Darurat Level IV sebagai standar minimal untuk Rumah Sakit Kelas A.

b. Pelayanan Instalasi Gawat Darurat Level III sebagai standar minimal untuk Rumah Sakit Kelas B.

c. Pelayanan Instalasi Gawat Darurat Level II sebagai standar minimal untuk Rumah Sakit Kelas C.

d. Pelayanan Instalasi Gawat Darurat Level I sebagai standar minimal untuk Rumah Sakit Kelas D.

Kemudian beberapa item pokok standar yang harus dipenuhi oleh IGD rumah sakit yaitu diantaranya adalah Standar Pelayanan Minimal dan Standar Sumber Daya Manusia. Batas waktu pencapaian target standar IGD bagi rumah sakit menurut Kepmenkes RI Nomer 856/Menkes/SK/IX/2009 yaitu paling lama lima tahun setelah dikeluarkannya SK oprasional IGD rumah sakit. Adapun sanksi administatif bagi rumah sakit yang tidak melaksanakan standar rumah sakit yaitu sesuai Pasal 27 Undang-Undang No. 44 tahun 2009 tentang Rumah Sakit bahwa "Ijin rumah sakit dapat dicabut jika sudah tidak memenuhi persyaratan atau standar". RSUD Bendan Kota Pekalongan adalah rumah sakit kelas $C$ yang sudah terakreditasi paripurna oleh lembaga akrediatsi KARS (Komisi Akreditasi Rumah Sakit) versi 2012 pada tahun 2017. IGD RSUD Bendan termasuk dalam klasifikasi pelayanan lavel II. Dalam pelayanan lavel II IGD RSUD Bendan harus sudah mempunyai SDM, Sarana dan Prasarana yang memadai seperti yang tercantum dalam 
Kepmenkes RI Nomer 856/Menkes/SK/IX/2009 Tentang Standar Instalasi Gawat Darurat Rumah Sakit. ${ }^{6}$

Dari hasil observasi yang peneliti lakukan IGD RSUD Bendan Kota Pekalongan belum sepenuhnya memenuhi pokok-pokok standar yang diatur dalam Kepmenkes RI Nomer 856/Menkes/SK/IX/2009 tentang Standar Instalasi Gawat Darurat. Pokok standar tersebut adalah sebagai berikut: 1 . Implementasi Standar Sumber Daya Manusia menurut Kepmenkes RI Nomer 856/Menkes/SK/IX/2009 Tentang Standar Instalasi Gawat Darurat Rumah Sakit oleh RSUD Bendan Kota Pekalongan. Standar SDM di IGD RSUD Bendan Kota Pekalongan sudah 90\% tercapai, seperti sudah tersedianya empat besar dokter spesialis: Bedah, Anak, Obsgyn dan Penyakit dalam on call. Dokter umum dan perawat DIII (Pelaksana/Vokasional) sudah dibekali pelatihan penunjang seperti BTCLS, BLS dan ATCLS, hanya saja IGD RSUD Bendan belum mempunyai perawat Profesional (Ners) atau S1. Sesuai Pasal 4 undang-undang No. 38 tahun 2014 tentang Keperawatan bahwa jenis perawat dibagi menjadi "Perawat Vokasi dan Profesi". Sedangkan Perawat Profesi dibagi menjadi Ners (S1) dan Ners Spesialis (S2). Ners mempunyai peranan dan tugas penting yaitu salah satunya sebagai pengambil keputusan dalam hal asuhan keperawatan, kemudian keputusan tersebut dilaksanakan oleh perawat pelaksana (voksional). Sedangkan Ners Spesialis yaitu sebagai Konsultan. Menurut Penanggung jawab IGD memang belum ada perawat profesional di IGD, "akan tetapi saya sudah menugaskan kepada salah satu perawat DIII sebagai ketua tim yang kebetulan sekarang sedang studi lanjut di Program Studi Keperwatan (S1)".

Direktur RSUD Bendan membenarkan hal tersebut memang belum ada hanya baru ada perawat DIII, semoga kedepan SDM dengan kriteriaS1 Ners tersebut terwujud demi mutu pelayanan kepada pasien, sehingga dengan demikian IGD RSUD Bendan dapat mengimplementasikan standar IGD secara utuh. 2. Implementasi Pelayanan minimal menurut Kepmenkes RI Nomer 856/Menkes/SK/IX/ 2009 Tentang Standar Instalasi Gawat Darurat Rumah Sakit oleh RSUD Bendan Kota Pekalongan. RSUD Bendan Kota Peklongan sudah mengimplmentasikan standar minimal pelayanan IGD dengan baik, hal ini di buktikan standar pelayanan minimal sudah hampir $90 \%$ tercapai, hanya saja angka kematian $\leq 24$ Jam masih tinggi yaitu enam per seribu, padahal angka standarnya adalah dua per seribu.

Hal ini berbeda dengan data yang disampaikan Direktur. Menurut direktur jika menggunakan standar indikator kematian $\geq 48$ Jam (Net Death Rate) angka kematianya adalah dua puluh delapan per seribu yang angka standarnya menurut Depkes 2010 adalah kurang dari empat puluh lima persen, jadi angka kematiannya rendah. Standar kematian di IGD sudah diatur dalam

${ }^{6}$ Buku Profil RSUD Bendan Kota Pekalongan 
Kepmenkes RI Nomer 856/Menkes/SK/IX/2009 tentang Standar Instalasi Gawat Darurat yaitu menggunakan indikator angka kematian $\leq 24$ jam dan standarnya adalah dua per seribu, jadi menurut peneliti angka kematian di IGD masih tinggi. Sedangkan NDR digunakan untuk mengukur kematian di layanan rawat inap. Menurut PJ IGD angka kematian yang tinggi tersebut tidak semata-mata karena kami terlambat melayani hal ini dapat dibuktikan dengan Emergency Respon Time (ERT) yang tercatat adalah empat menit yang standarnya adalah kurang dari lima menit. "Saya berkesimpulan bahwa kematian tersebut karena penyakit fase terminal dan proses merujuk ke IGD RSUD Bendan yang terlambat" ${ }^{7}$

Maka dengan itu RSUD Bendan sudah seharusnya mengimlementasikan semua standar baik persyaratan SDM dan persyaratan pelayanan minimal. Karena dengan telah diimplementasikan suatu kebijakan baru akan dapat terlihat dampaknya bagi masyarakat, baik dampak positif maupun dampak negatif. Dampak negatif akan cenderung mengancam keselamatan pasien sehingga hak-hak pasien menjadi terabaikan. Keselamatan pasien itu sendiri dijamin dalam Pasal 4 Permenkes RI Nomor 11 tahun 2017 Tentang Keselamatan Pasien, yang standarnya meliputi:
a. Hak pasien;
b. Pendidikan bagi pasien dan keluarga;
c. Keselamatan Pasien dalam kesinambungan pelayanan;
d. Penggunaan metode peningkatan kinerja untuk melakukan evaluasi dan peningkatan Keselamatan Pasien;
e. Peran kepemimpinan dalam meningkatkan Keselamatan Pasien;
f. Pendidikan bagi staf tentang Keselamatan Pasien; dan,
g. Komunikasi merupakankunci bagi staf untuk mencapai Keselamatan Pasien.

Kemudian dalam hal control dan pengawasan terhadap penjaminan keselamatan pasien, direktur rumah sakit dan kepala IGD diperintahkan untuk melaksanakan tugas tersebut, seperti yang tertuang dalam Pasal 10 ayat (1). Standar peran kepemimpinan dalam meningkatkan Keselamatan Pasien sebagaimana dimaksud dalam Pasal 5 ayat (4) huruf (e) merupakan kegiatan pimpinan fasilitas pelayanan kesehatan dalam:

a. Mendorong dan menjamin implementasi Keselamatan Pasien secara terintegrasi dalam organisasi melalui penerapan tujuh langkah menuju Keselamatan Pasien;

b. Menjamin berlangsungnya kegiatan identifikasi risiko Keselamatan Pasien dan menekan atau mengurangi insiden secara proaktif;

${ }^{7}$ Hasil wawancara dengan Direktur RSUD Bendan Kota Peklaongan 
c. Menumbuhkan komunikasi dan koordinasi antar unit dan individu berkaitan dengan pengambilan keputusan tentang Keselamatan Pasien;

d. Mengalokasikan sumber daya yang adekuat untuk mengukur, mengkaji, dan meningkatkan kinerja fasilitas pelayanan kesehatan serta meningkatkan Keselamatan Pasien; dan

e. Mengukur dan mengkaji efektifitas kontribusi setiap unsur dalam meningkatkan kinerja fasilitas pelayanan kesehatan dan Keselamatan Pasien.

Dengan demikian rumah sakit berkewajiban memberikan hak-hak pasien secara utuh, supaya hak-hak pasien tersebut terjamin maka perlu pengawasan oleh kepala IGD dan direktur terhadap perawat dan dokter sebagai petugas yang memberi pelayanan kesehatan kepada pasien, karena itu merupakan bagian dari penerapan hukum di rumah sakit. Menurut Hardiati hubungan hukum antara pasien dan rumah sakit disebut "Inspaninnings Verbintanis" (iktiar sebaik-bainya menurut standar yang berlaku) yaitu merupakan hubungan hukum antara dua subjek hukum (si sakit dan si pengobat) yang melahirkan hak dan kewajiban. ${ }^{8}$

\section{Faktor Pendukung dan Penghambat Implementasi SDM Menurut} Kepmenkes RI No.856/Menkes/SK/IX/2009 tentang Standar Instalasi Gawat Darurat Rumah Sakit

Menurut Direktur RSUD Bendan Kota Pekalongan terlaksananya capaian standar instalasi gawat darurat adalah berkat kerja keras semua pihak. Pertama, Pemerintah kota selaku pemilik rumah sakit juga memperhatikan kebutuhan pengembangan rumah sakit ini, sebagai contoh kongritnya adalah melalui Badan Kepegawaian Daerah sudah memberikan ijin belajar kepada para SDM dilingkungan RSUD Bendan Kota Pekalongan untuk meningkatkan keilmuanya.

Kedua, IGD RSUD Bendan memiliki SDM yang semangat dalam bekerja dan dapat dipertanggungjawabkan. Hal ini dapat dibuktikan dengan Indikator Pelayanan Minimal IGD bahwa waktu tanggap darurat adalah 4 menit dan tingkat kepuasan pasien 78\% versi Kepala Instalasi, yang artinya itu sudah sesuai standar. Ketiga, Adanya pertemuan rutin antara pemangku kebijakan rumah sakit dengan pemerintah sehingga dalam forum tersebut rumah sakit dapat menyampaikan usulan-usaulan langsung kepada Pemerintah. Hal ini merupakan bentuk komunikasi yan baik antara menejemen rumah sakit dengan pemerintah selaku pemilik rumah sakit.

${ }^{8}$ Raharjo Sajipto, 2012. Ilmu Hukum, cetakan ke 7. Bandung: Citra Aditya Bakti, hlm. 153 
Dalam melaksanakan kepetusan menteri tentang Standar Instalasi Gawat Darurat Rumah Sakit ada beberapa kendala yang ditemui antara lain: Pertama, SDM Perawat SI Ners belum dimiliki oleh IGD RSUD Bendan Kota Pekalongan, Kesibukan yang tinggi perawat di IGD sehingga kesulitan membagi waktu untuk mengambil pendidikan ke jenjang yang lebih tinggi, selain itu faktor biaya dan jarak kampus juga menjadi kendala. Apalagi ditambah Badan Kepegawaian Daerah Kota Pekalongan Mensyaratkan jika akan melanjutkan kuliah harus masuk ke perguruan tinggi yang telah terakreditasi B, Saat ini jarak paling dekat adalah Kota Semarang sehingga tidak mungkin untuk mendaftar. RSUD Bendan juga belum punya anggaran khusus untuk alokasi peningkatan pendidikan SDM, Kalau untuk pelatihanpelatihan terkait penyegaran dan peningkatan kompetensi tentu ada anggran. Kedua, kurangnya pengawasan dan pembinaan oleh Dewan Pengawas Rumah Sakit (Dewas RS), sehingga tidak diperhatikannya kendali mutu pelayanan, pelaksanaan etika, dan pegusulan kebijakan yang lain seperti: rencana anggaran belanja. Ketiga, kurangnya informasi tentang standar IGD oleh tenaga kesehatan di IGD RSUD Bendan dan kurangnya komunikasi antar struktural membuat kebijakan sulit berjalan.

\section{Kesimpulan}

Standar Instalasi Gawat Darurat diatur dalam Undang-Undang No. 44 tahun 2009 tentang Rumah Sakit. Secara khusus Standar IGD telah diatur dalam Kepmenkes RI No.856/Menkes/SK/IX/2009 tentang standar Instalasi Gawat Darurat Rumah Sakit. Tetapi dalam kenyataan dilapangan, Rumah Sakit belum mengimplementasikan peraturan tersebut secara penuh, sehingga mutu pelayanan di IGD menjadi kurang. Dengan demikian hak pasien untuk mendapatkan pelayanan yang bermutu menjadi terabaikan. Menurut UndangUndang Rumah Sakit Pasal 29 Ayat 1 butir (a) bahwa "Rumah Sakit berkewajiban memberi pelayanan kesehatan yang aman, bermutu, antidiskriminasi, dan efektif dengan mengutamakan kepentingan pasien sesuai dengan standar pelayanan Rumah Sakit". Adapun faktor pendukung implementasi yaitu motivasi Sumber Daya Manusia yang tinggi dan faktor penghambatnya yaitu kesempatan dan biaya studi lanjut bagi perawat belum ada.

\section{REFRENCES}

Herlambang Susatyo, (2016), Manajemen Pelayanan Kesehatan Rumah Sakit, Yogyakarta: Gosyen Publishing, hlm. 33

Rudy Limantara, 2015, Faktor-faktor yang Mempengaruhi Tingginya Angka Kematian di IGD Rumah Sakit, Jurnal Kedokteran Brawijaya, Vol. 28, Suplemen No. 2. 
Agus Purwanto Erwan, (2015). Implementasi Kebijakan Publik: Konsep dan Aplikasinya di Indonesia. Yogyakarta: Gava Media.

Jarot Digdo Ismoyo, The Model of Management of the Masela Block Based on People's Welfare in Maluku, Jurnal Bestuur Vol. 8, Issue 2, December, 2020. Raharjo Sajipto, (2012). Ilmu Hukum, cetakan ke 7. Bandung: Citra Aditya Bakti. Jaelani, A.K, Implementasi Daluarsa Gugatan Dalam Putusan Peradilan Tata Usaha Negara di Indonesia, Pena Justisia: Media Komunikasi dan Kajian Hukum. Volume 18, No. 2, 2019.

Hanum, W.N, Setting of Earth Oil Management in Old Wells Based on the Principle Social Justice, Jurnal Bestuur Vol. 8, Issue 2, December, 2020.

Intaniasari, Kirana, Gross Split Contract Framework Regulation on the Caring for People, Jurnal Bestuur Vol. 8, Issue 2, December, 2020.

Saputra, Rian, Development of Creative Industries as Regional Leaders in National Tourism Efforts Based on Geographical Indications, Jurnal Bestuur Vol. 8, Issue 2, December, 2020.

Akhmaddhian, Suwari. Discourse on Creating a Special Environmental Court in Indonesia to Resolve Environmental Disputes, Jurnal Bestuur Vol. 8, Issue 2, December, 2020.

Pane, E \& Yanis, A.M, Reconstruction of Mining Policies on Justice in Lampung Province, Jurnal Bestuur Vol. 8, Issue 2, December, 2020.

Gunawan, Said, The Principle of Control of Non Primary Gun System of the Indonesian National Army Protect Soldiers, Jurnal Bestuur Vol. 8, Issue 2, December, 2020.

Luthviati, R.D, The Role of Local Governments in the Defense of Leading Products, Jurnal Bestuur Vol. 8, Issue 2, December, 2020.

Abdul Kadir Jaelani, "Implementasi Daluarsa Gugatan Dalam Putusan

Peradilan Tata Usaha Negara Di Indonesia", Jurnal Pena Justisia, Vol.18,

Nomor 2 Tahun 2019.

Nurika Latiff Hikmawati "Efektivitas Penerapan Sanksi Pidana Penjara Terhadap Anak Yang Melakukan Tindak Pidana", Jurnal Pena Justisia, Vol.18, Nomor 2 Tahun 2019.

Miftahur Rahman Hakim, Nur Kholidah, "Hak Merek Sebagai Jaminan Gadai Untuk Permodalan Umkm Industri Kreatif Kerajinan Batik", Jurnal Pena Justisia, Vol.18, Nomor 2 Tahun 2019.

Vidya Noor Rachmadini "Perlindungan Hukum Bagi Investor Dalam Pasar Modal Menurut Undang-Undang Pasar Modal Dan Undang-Undang Otoritas Jasa Keuangan", Jurnal Pena Justisia, Vol.18, Nomor 2 Tahun 2019. 